Beata IWANicka, AleKSANDRA RożeK Uniwersytet im. Adama Mickiewicza w Poznaniu

\title{
Sprawozdanie z Seminarium Naukowego "Aktualne tendencje we wspomaganiu rozwoju dzieci i ich rodzin", Wydział Studiów Edukacyjnych, Poznań, 18 maja 2017 r.
}

18 maja 2017 r. na Wydziale Studiów Edukacyjnych Uniwersytetu im. Adama Mickiewicza w Poznaniu odbyło się Seminarium Naukowe pt. "Aktualne tendencje we wspomaganiu rozwoju dzieci i ich rodzin", zorganizowane przez Zakład Psychopatologii Dziecka. Celem tego wydarzenia była wymiana doświadczeń w zakresie specjalistycznych działań na rzecz wspierania rozwoju dzieci i ich rodzin.

Seminarium uświetniła swoją obecnością prof. zw. dr hab. Edyta Gruszczyk-Kolczyńska z Akademii Pedagogiki Specjalnej im. Marii Grzegorzewskiej $\mathrm{w}$ Warszawie. Ponadto uczestniczyli w nim pracownicy naukowo-dydaktyczni i doktorantki z Zakładu Psychopatologii Dziecka WSE UAM, specjaliści pracujący w ośrodkach wczesnego wspomagania rozwoju dziecka w Poznaniu, studenci, nauczyciele oraz przedstawiciele placówek oświatowo-wychowawczych z Wielkopolski.

Seminarium rozpoczął prof. zw. dr hab. Andrzej Twardowski, kierownik Zakładu Psychopatologii Dziecka, który przywitał zgromadzonych uczestników. Oficjalnego otwarcia seminarium dokonała Dziekan Wydziału Studiów Edukacyjnych, prof. zw. dr hab. Agnieszka Cybal-Michalska, podkreślając znaczenie ciągłości misji, jaka towarzyszy pedagogice specjalnej oraz zmiany paradygmatycznej w podejściu do niepełnosprawności.

Wykład inauguracyjny na temat Uzdolnione matematycznie dzieci: mity, wyniki badań, interpretacje $i$ zastosowania wygłosiła prof. zw. dr hab. Edyta 
Gruszczyk-Kolczyńska z Akademii Pedagogiki Specjalnej im. Marii Grzegorzewskiej w Warszawie. W swoim wystąpieniu badaczka zwróciła uwagę na fakt, iż zagadnieniu uzdolnień matematycznych dzieci towarzyszy bardzo wiele mitów i nieporozumień. Między innymi funkcjonuje błędne przekonanie, iż zdolności matematyczne mogą manifestować tylko starsi uczniowie, tuż przed maturą, zajmujący się "zaawansowaną" matematyką, a do opanowania matematyki podstawowej potrzebne są uzdolnienia, które posiada tylko 8-12\% dzieci, wobec czego odnotowuje się tak liczne niepowodzenia w nauce matematyki. Referentka wielokrotnie odwoływała się do wyników badań prowadzonych w Polsce i na świecie. Ponadto wskazała i szczegółowo omówiła cechy umysłu, które posiadają dzieci uzdolnione matematycznie. $\mathrm{Z}$ punktu widzenia problematyki seminarium bardzo istotną kwestią, poruszoną przez prof. zw. dr hab. Edytę Gruszczyk-Kolczyńską, było omówienie wyników badań w zakresie uzdolnień matematycznych wśród dzieci z niepełnosprawnościami i uczniów o specjalnych potrzebach edukacyjnych.

Jako drugi wystąpił prof. zw. dr hab. Andrzej Twardowski, wygłaszając referat Rówieśniczy tutoring we wczesnym wspomaganiu rozwoju dzieci $z$ niepetnosprawnościami. We wstępie zwrócił on uwagę na fakt, że kontakty z rówieśnikami pozytywnie wpływają na rozwój ruchowy, poznawczy, społeczny i emocjonalny dziecka. Ponadto scharakteryzował rodzaje nauczających interakcji z rówieśnikami, do których należą: uczenie się przez rówieśnika (ang. peer tutoring), uczenie się z rówieśnikiem (ang. peer collaboration) oraz uczenie się zespołowe (ang. cooperative learning). W dalszej części wystąpienia prelegent wskazał na czym powinno polegać przygotowanie pełnosprawnych dzieci do roli tutorów, wymienił jego korzyści, a także omówił rolę nauczyciela jako organizatora rówieśniczego tutoringu. W podsumowaniu autor podkreślił szczególne znaczenie rówieśniczego tutoringu dla edukacji integracyjnej.

Jako kolejna wystąpiła dr Maria Paula Stasiakiewicz, która wygłosiła referat zatytułowany Masaż Shantala jako dialog niemowlęcia i jego dorosłego opiekuna. Na początku przybliżyła kwestie teoretyczne dotyczące wrodzonego wyposażenia człowieka do uczestnictwa w dialogu. W swoim wystąpieniu wiele uwagi poświęciła zagadnieniu wrodzonej intersubiektywności, uważanej za cechę ludzkiej konstytucji, będącej podstawą cielesnego i emocjonalnego self jednostki. Badaczka omówiła również istotę masażu Shantala, ukierunkowanego na budowanie relacji i dialogu. Treść referatu uzupełniał materiał filmowy ukazujący dialog niemowlęcia z matką oraz instruktaż dotyczący wykonania masażu Shantala. 
Po przerwie kawowej głos zabrały dr hab. Danuta Kopeć prof. UAM oraz dr hab. Hanna Kubiak, przedstawiając temat: Zastosowanie metody videotreningu (VIPP-SD) w pracy z rodzicami dzieci z grupy ryzyka rozwojowego. Zaprezentowana technika ma służyć wspieraniu opiekunów i ich rodzicielską responsywność i uważność. Co wyraźnie podkreśliły mówczynie, najważniejsza jest rola rodzica, natomiast rola terapeuty sprowadza się do pełnienia funkcji bezpiecznej bazy dla diady w procesie przepracowania trudności relacyjnych. Autorki odniosły się do badań empirycznych, które wykazały, że interwencje terapeutyczne mają statystycznie większy wpływ na wrażliwość rodzicielską.

Następny referat na temat Schizofrenia $u$ dzieci zaprezentowała dr Małgorzata Cichecka-Wilk. Prelegentka scharakteryzowała diagnozę różnicową choroby w wybranej grupie oraz jej rozpoznanie. Omówiła przebieg schizofrenii u dzieci oraz przyczyny jej powstawania. Przedstawiła również przypadek kliniczny chorego psychicznie chłopca. W tej części zaprezentowała powód interwencji psychiatrycznej, wywiad zebrany od rodziców, nauczycieli, wyniki badań oraz rozmowy z samym małym pacjentem.

Kolejne wystąpienie, autorstwa Marii Stec, nosiło tytuł Wczesne wspomaganie rozwoju dzieci $w$ rodzinach adopcyjnych. Referentka próbowała dowieść, dlaczego warto objąć wczesnym wspomaganiem dzieci w rodzinach adopcyjnych. Omówiła obszar oddziaływania rodziny na dziecko, skutki zerwania więzi biologicznej oraz sytuację w nowej rodzinie dziecka, które wcześniej zostało odrzucone emocjonalnie. Zwróciła także uwagę na przebieg procesów psychicznych $u$ dziecka odtrąconego przez pierwszych opiekunów. W konkluzjach autorka wskazała, jak ważne jest zdiagnozowanie interakcji dziecka z matką i ojcem adopcyjnym. Wskazała na główną zasadę pracy terapeutycznej, która mówi, że z dzieckiem zawsze należy pracować poprzez rodziców, ponieważ z nimi powinno ono wytworzyć więź.

Ostatni referat na temat Wsparcie techniczne w procesie wspomagania rozwoju dzieci z wada stuchu wygłosiła mgr Beata Iwanicka. W swoim wystąpieniu referentka zaznaczyła, że w celu zoptymalizowania procesu edukacji wymienionej grupy dzieci istotne jest, aby zadbać o zmniejszenie barier architektonicznych oraz zapewnić odpowiednie wsparcie techniczne. Bez tego ostatniego elementu niemożliwe jest usprawnienie procesu komunikacji. Prelegentka przedstawiła urządzenia, które w znaczący sposób mogą wpłynąć na rozumienie przez dziecko dźwięków płynących z otaczającej je przestrzeni. Są to różnorodne aparaty oraz sprzęt wspomagający, użytecz- 
ny także w pracy z większą grupą wychowanków z wadą słuchu. Co szczególnie istotne, prawidłowe zastosowanie rozwiązań technicznych pozwala zmniejszyć bądź wyeliminować wykluczenie społeczne uczniów niesłyszących.

Zakończenia i podsumowania seminarium dokonał prof. zw. dr hab. Andrzej Twardowski. Podziękował on prelegentom i zebranym słuchaczom za udział w obradach i dyskusji. Wyraził nadzieję, że przedstawione badania znajdą zastosowanie $\mathrm{w}$ praktyce edukacyjnej, a zaprezentowana wiedza okaże się przydatna w codziennej pracy z dziećmi niepełnosprawnymi oraz zagrożonymi niepełnosprawnością. 